\title{
Major Salivary Gland Cancer Pathologic Distant Metastasis TNM Finding v6
}

National Cancer Institute

\section{Source}

National Cancer Institute. Major Salivary Gland Cancer Pathologic Distant Metastasis

TNM Finding v6. NCI Thesaurus. Code C65073.

A pathologic finding about one or more characteristics of major salivary gland cancer, following the rules of the TNM AJCC v6 classification system as they pertain to distant metastases. 